\title{
PENGARUH UKURAN PERUSAHAAN DAN PERTUMBUHAN PERUSAHAAN TERHADAP KEBIJAKAN HUTANG PADA SEKTOR KONSUMSI PERIODE 2015-2020
}

\section{Yusdianto, Achmad Ramadhoni, Sutanto Hardisaputera}

Universitas Persada Indonesia Y.A.I, Indonesia

Email: y.anton1977@gmail.com, adhoni@yahoo.com, sutantohs14@gmail.com

\begin{tabular}{ll}
\hline INFO ARTIKEL & ABSTRAK \\
\hline Diterima & Penelitian ini bertujuan untuk menguji pengaruh Ukuran \\
25 Oktober 2021 & Perusahaan dan Pertumbuhan perusahaan terhadap Kebijakan \\
Direvisi & Hutang. Populasi penelitian ini adalah perusahaan manufaktur \\
05 November 2021 & sektor industry barang konsumsi yang terdaftar di Bursa Efek \\
Disetujui & Indonesia (BEI) periode 2015-2020. Berdasarkan hasil purposive \\
15 November 2021 & sampling diperoleh 12 perusahaan manufaktur sektor industri \\
\hline Kata Kunci: & barang konsumsi yang memenuhi kriteria sampel. Pengujian di \\
ukuran perusahaan; & dalam penelitian ini menggunakan bantuan software Eviews 9.0. \\
pertumbuhan & Hasil penelitian ini menunjukkan bahwa Hasil uji regresi secara \\
perusahaan dan & parsial menunjukan ada pengaruh Ukuran Perusahaan terhadap \\
kebijakan hutang & Kebijakan Hutang pada tingkat signifikan $\alpha=0.05$, terlihat dari \\
& hasil uji t yang dilakukan diperoleh t hitung sebesar -2.930846 \\
& dengan probabilitas sebesar 0.0061 < 0.05. Hasil uji resresi \\
& secara parsial menunjukan ada pengaruh Pertumbuhan \\
& Perusahaan terhadap Kebijakan Hutang pada tingkat signifikan $\alpha$ \\
& $=0.05$, terlihat dari hasil uji t yang dilakukan diperoleh thitung \\
& sebesar 3.234059 dengan probabilitas sebesar 0.0028 < 0.05. \\
& Hasil uji regresi secara bersama-sama menunjukkan pengaruh \\
& Ukuran Perusahaan, dan Pertumbuhan Perusahaan dengan \\
& melakukan uji F diperoleh Fhitung sebesar 496.8447. Ukuran \\
& Perusahaan dan Pertumbuhan Perusahaan secara bersama-sama \\
berpengaruh terhadap Kebijakan Hutang.
\end{tabular}

\section{ABSTRACT}

This study aims to examine the effect of firm size and firm growth on debt policy. The population of this study are manufacturing companies in the consumer goods industry sector listed on the Indonesia Stock Exchange (IDX) for the 2015-2020 period. Based on the results of purposive sampling, there were 12 manufacturing companies in the consumer goods industry that met the sample criteria. Testing in this study using the help of software Eviews 9.0. The results of this study indicate that the results of the partial regression test show that there is an effect of Firm Size on Debt Policy at a significant level $=0.05$, it can

$\begin{array}{ll}\text { How to cite: } & \text { Yusdianto, Y., Achmad Ramadhoni, \& Sutanto Hardisaputera. (2021) Pengaruh Ukuran Perusahaan } \\ & \text { dan Pertumbuhan Perusahaan Terhadap Kebijakan Hutang pada Perusahaan Sektor Industri Barang } \\ & \text { Konsumsi Periode 2015-2020. Jurnal Syntax Admiration 2(11). } \\ & \text { https://doi.org/10.46799/jsa.v2i11.346 } \\ & 2722-5356 \\ \text { E-ISSN: } & \text { Ridwan Institute } \\ \text { Published by: } & \end{array}$


be seen from the results of the t test carried out that the tcount is -2.930846 with a probability of $0.0061<0.05$. The results of the partial recession test show that there is an effect of Company Growth on Debt Policy at a significant level $=0.05$, it can be seen from the results of the t-test carried out that tcount is 3.234059 with a probability of $0.0028<0.05$. The results of the Keywords: $\quad$ regression test together show the effect of firm size and firm company size; growth by performing the $F$ test, the Fcount is 496.8447. company growth Company Size and Company Growth together affect the Debt and debt policy Policy.

\section{Pendahuluan}

Perkembangan dewasa ini perusahaan-perusahaan yang sedang berkembang maupun perusahaan yang baru memulai usahanya tidak terlepas kepada kebutuhan akan modal yang cukup besar untuk melaksanakan proses pencapaian usaha yang berkesinambungan. Kesiapan perusahaan dalam mengelola usaha ditandai dengan kecukupan akan dana operasional yang memadai, maka untuk hal ini perusahaan akan banyak membutuhkan dana yang berasal dari penanaman modal maupun dengan berhutang kepada pihak ketiga, dalam hal ini bank atau lembaga keuangan yang menunjang. Namun inisiatif ini harus dapat dicermatinya terlebih kepada pinjaman kepihak ketiga karena hutang yang berlebih yang tidak tepat sasaran akan menimbulkan dampak secara langsung kepada likuiditas perusahaan kedepannya.

Sebagaimana yang diutarakan pada penelitian terdahulu yakni sumber dana dari kreditur merupakan hutang bagi perusahaan. Hutang bagaikan dua sisi mata uang bagi perusahaan yaitu memiliki dampak positif maupun dampak negatif. Pada tingkat tertentu, hutang mampu menciptakan suatu sistem pengawasan terhadap perusahaan serta dapat digunakan untuk penghematan pajak sehingga dapat meningkatkan nilai perusahaan (Astuti, 2015).

Tujuan perusahaan adalah mencari laba dan mempertahankan kelangsungan hidupnya. Dalam kegiatannya mencari laba, pemilik memberi wewenang kepada manajemen untuk melaksanakannya. Dalam usahanya memperoleh laba, manajemen harus berperilaku : Memaksimumkan nilai perusahaan, artinya manajemen harus mengahasilkan laba lebih besar dari biaya modal yang digunakannya, tanggung jawab sosial, artinya dalam mencari laba, manajemen tidak boleh merusak lingkungan alam, sosial, dan budaya, etika artinya manajemen dalam mengusahakan laba harus tunduk pada norma-norma sosial di lingkungan mereka bekerja dan tidak boleh menipu masyarakat konsumen (Mulyanti, 2017).

Menurut (Riyanto, 2001) dalam Aries (Veronica, 2020), Kebijakan hutang merupakan keputusan yang sangat penting dalam perusahaan. Dimana kebijakan hutang merupakan salah satu bagian dari kebijakan pendanaan perusahaan. Kebijakan hutang adalah kebijakan yang diambil pihak manajemen dalam rangka memperoleh sumber daya pembiayaan bagi perusahaan sehingga dapat digunakan untuk membiayai aktivitas operasional perusahaan. 
Semakin besar ukuran perusahaan diharapkan dapat meningkatkan laba perusahaan. Apabila perusahaan dengan ukuran perusahaan yang besar menghasilkan laba yang kecil akan menjadi sinyal negatif bagi para investor.

Hasil penelitian (Sumarsono, 2016) dalam (Gustian, 2017) menyatakan bahwa pertumbuhan perusahaan berpengaruh positif dan signifikan terhadap nilai perusahaan memberikan arti bahwa setiap adanya peningkatan aset yang dimiliki oleh suatu perusahaan merupakan suatu sinyal yang positif bagi investor, pertumbuhan aset yang positif juga memberikan arti bahwa manajemen telah mampu mengelola perusahaan dengan baik.

Berdasarkan latar belakang masalah yang telah diuraikan diatas, dapat dibedakan bahwa untuk variabel dependen berupa kebijakan hutang berkaitan dangan sektor industri barang konsumsi sangat jarang diteliti oleh peneliti terdahulu.

Penelitian ini diharapkan dapat bermanfaat secara teoritis penelitian ini diharapkan dapat memberikan tambahan keilmuan bagi penulis, memperkuat penelitian terdahulu, dan dapat memberikan kontribusi pada pengembangan penelitian dibidang akuntansi maupun juga dapat dijadikan referensi dan perbandingan bagi penelitian selanjutnya. Kemudian secara praktis memberikan kontribusi berupa sumbangan pemikiran, memberikan tambahan pengetahuan dan wawasan yang berhubungan dengan Kebijakan Hutang Perusahaan, maka penulis tertarik untuk melakukan penelitian lebih lanjut mengenai kebijakan hutang pada sektor tersebut. Adapun judul yang penulis tuangkan dari penilitan ini adalah: "Pengaruh Ukuran Perusahaan Dan Pertumbuhan Perusahaan Terhadap Kebijakan Hutang Pada Sektor Industri Barang Konsumsi Yang Terdaftar Di Bursa Efek Indonesia (BEI) Tahun 2015 - 2020”.

\section{Metode Penelitian}

1. Jenis Penelitian

Jenis penelitian yang digunakan dalam penelitian ini adalah kausal komperatif (casual - comparative research), Peneliti melakukan pengamatan terhadap konsekuensi-konsekuensi yang timbul dan menelusuri Kembali fakta yang secara masuk akal sebagai faktor-faktor penyebabnya. Peneliti dapat mengidentifikasi fakta dan peristiwa tersebut sebagai variabel yang dipengaruhi (variabel dependen) dan melakukan penyidikan terhadap variabel-variabel yang mempengaruhi (variabel independent).

2. Operasional Variabel

Penelitian ini terdapat tiga variabel independen $(\mathrm{X})$ yaitu Ukuran Perusahaan dan Pertumbuhan Perusahaan. Serta satu variabel dependen (Y) yaitu Kebijakan Hutang.

3. Variabel Independen

a. Ukuran Perusahaan (X1)

Ukuran perusahaan merupakan besar kecilnya suatu perusahaan yang dapat dilihat dari total asset. Ukuran perusahaan dalam penelitian ini dihitung dengan logaritma natural dari total asset yang dimiliki perusahaan. 


\section{SIZE $=\log$ Natural $x$ Total Aset}

b. Pertumbuhan Perusahaan (X2)

Pertumbuhan perusahaan dapat didefinisikan sebagai peningkatan yang terjadi pada suatu perusahaan. Perusahaan yang bertumbuh pesat cenderung lebih banyak menggunakan hutang daripada perusahaan yang bertumbuh secara lambat.

\section{GROWTH: Total Aktiva Akhir Tahum}

4. Variabel Dependen (Y)

a. Kebijakan Hutang

Kebijakan hutang merupakan kebijakan perusahaan yang bersumber eksternal. Kebijakan hutang sering diukur menggunakan Debt to Equity Ratio yang mencerminkan kemampuan perusahaan dengan menggunakan semua kewajibannya yang ditunjukkan oleh Sebagian modal sendiri yang digunakan untuk membayar hutang perusahaan.

$$
\text { DER }=\frac{\text { Total Hutang }}{\text { Total Ekuitas }} \times 100 \%
$$

5. Populasi dan Sampel

Populasi dalam penelitian ini adalah perusahaan manufaktur sektor industri barang konsumsi yang menerbitkan laporan keuangan yang terdaftar di Bursa Ffek Indonesia (BEI). Jumlah sampel dalam penelitian ini sebanyak 12 perusahaan.

Metode penentuan sampel yang digunakan dalam penelitian ini adalah dengan purposive sampling. Purposive sampling adalah Teknik penentuan sampel dengan pertimbangan tertentu.

6. Jenis Data, Sumber Data dan Metode Pengumpulan Data

Jenis daya yang digunakan dalam penelitian ini yaitu data yang berupa angka angka laporan keuangan masing - masing perusahaan, data yang dipilih terdiri atas ukuran perusahaan dan pertumbuhan perusahaan.

Penelitian ini, data diambil dari Bursa Efek Indonesia (BEI) berupa laporan keuangan perusahaan manufaktur barang konsumsi yang terdaftar di IDX statistic, website www.idx.co.id untuk mendapatkan data yang diinginkan yang dilakukan dengan observasi tidak langsung. 
Pengaruh Ukuran Perusahaan dan Pertumbuhan Perusahaan Terhadap Kebijakan

Hutang pada Perusahaan Sektor Industri Barang Konsumsi Periode 2015-2020

\section{Hasil dan Pembahasan}

\section{A. Hasil Penelitian}

1. Analisis Statistik Deskriptif

Tabel 1

Hasil Uji Statistik Deskriptif

\begin{tabular}{cccc}
\hline Mean & $\begin{array}{c}\text { Size } \\
\mathbf{2 9 . 0 9 2 4 4}\end{array}$ & $\begin{array}{c}\text { Growth } \\
\mathbf{1 . 1 1 1 8 2 8}\end{array}$ & $\begin{array}{c}\text { Der } \\
\mathbf{0 . 7 8 5 2 1 8}\end{array}$ \\
\hline Median & 28.74760 & 1.081539 & 0.620371 \\
Maximum & 32.20096 & 1.620343 & 2.530450 \\
\hline Minimum & 25.79571 & 0.900558 & 0.163544 \\
\hline Std. Dev. & 1.783737 & 0.136498 & 0.588265 \\
Skewness & 0.171994 & 1.679186 & 1.639702 \\
\hline Kurtosis & 2.345054 & 6.646834 & 5.285397 \\
\hline Jarque-Bera & 1.094563 & 49.15614 & 31.95507 \\
\hline Probability & 0.578520 & 0.000000 & 0.00000 \\
\hline Sum & 1396.437 & 53.36776 & 37.69048 \\
Sum Sq. Dev. & 149.5407 & 0.875686 & 16.26462 \\
\hline Observations & 72 & 72 & 72 \\
\hline Suber : hasil & & &
\end{tabular}

Sumber : hasil olahan e-views

Dari tabel diatas menunjukan penelitian ini mempunyai 72 data pengamatan dan dapat dianalisis.

Nilai rata-rata Ukuran Perusahaan pada periode tahun 2015-2020 sebesar 29.09244, dengan nilai standar deviasi sebesar 1.783737. Perusahaan yang memiliki nilai Ukuran Perusahaan tertinggi sebesar 32.30096 yaitu PT. Indofood Sukses Makmur Tbk pada periode 2018, sedangkan nilai Ukuran Perusahaan terendah sebesar 25.79571 yaitu PT. Pyridam Farma Tbk pada periode 2017.

Nilai rata-rata Pertumbuhan Perusahaan pada periode tahun 2015-2020 sebesar 1.111828, dengan nilai standar deviasi sebesar 0.136498. Perusahaan yang memiliki nilai Pertumbuhan Perusahaan tertinggi sebesar 1.620343 yaitu PT. Indofood Sukses Makmur Tbk pada periode 2018, sedangkan nilai Pertumbuhan Perusahaan terendah sebesar 0.900558 yaitu PT. Pyridam Farma Tbk pada periode 2017.

Nilai rata-rata Kebijakan Hutang yang diproksikan oleh DER pada periode tahun 2015-2020 sebesar 0.785218, dengan nilai standar deviasi sebesar 0.588265. Perusahaan yang memiliki nilai Kebijakan Hutang tertinggi sebesar 2.530450 yaitu PT. Tunas Baru Lampung Tbk pada periode 2016, sedangkan nilai Kebijakan Hutang terendah sebesar 0.163544 yaitu PT. Ultra Jaya Milk Industry \& Tra periode 2018 (Dewi, Gusti Ayu Rencana Sari, 2018).

\section{Analisis Regresi Data Panel}

Berdasarkan hasil regresi data panel maka dapat disimpulkan bahwa Fixed Effect Model (FEM) merupakan model pendekatan yang tepat untuk digunakan. 


\section{Hasil Regresi Fixed Effect Model}

Tabel 2.

Dependent Variable : DER

Method: Panel EGLS (Cross-Section Weights)

Date : 07/21/21 Time: $21: 24$

Sample : 2015:20.20

Periods induded : 6

Cross-Sections induded: 12

Total Panel (Balan Ced) Observations : 72

Linear Estimation after One-step Wei Ghting Matrix

\begin{tabular}{|c|c|c|c|c|}
\hline Variable & Coeffcient & Std. Error & t-Statistic & Prob \\
\hline $\mathrm{C}$ & 7.436300 & 2.692882 & 2.761486 & 0.0093 \\
\hline Size & -0.282479 & 0.096381 & -2.930846 & 0.0061 \\
\hline Growth & 1.018572 & 0.314952 & 3.234059 & 0.0028 \\
\hline \multicolumn{5}{|c|}{ Effects Specifcation } \\
\hline \multicolumn{5}{|c|}{ Cross-Section Fixed (Dummy Variables) } \\
\hline \multicolumn{5}{|c|}{ Weighted Statistics } \\
\hline & 0.994240 & $\begin{array}{l}\text { Mean } \\
\text { dependent }\end{array}$ & 1.362756 & \\
\hline \multirow[t]{2}{*}{ Squared } & 0.991796 & Var & & \\
\hline & & $\begin{array}{l}\text { S.D. } \\
\text { Dependent } \\
\text { Var }\end{array}$ & 1.510088 & \\
\hline $\begin{array}{l}\text { S.E.Of } \\
\text { Regression }\end{array}$ & 0.123063 & $\begin{array}{l}\text { Sum Squared } \\
\text { Resid }\end{array}$ & 0.499766 & \\
\hline F-Statistoc & 406.8447 & $\begin{array}{l}\text { Durbin- } \\
\text { Watson Stat }\end{array}$ & 2.086462 & \\
\hline \multicolumn{5}{|c|}{ Unweighted Statistics } \\
\hline$R$-Squared & 0.938108 & $\begin{array}{l}\text { Mean } \\
\text { Dependent }\end{array}$ & 0.785218 & \\
\hline $\begin{array}{l}\text { Sum Squared } \\
\text { Resid }\end{array}$ & & Var & 2.202766 & \\
\hline
\end{tabular}

Sumber : hasil olahan data e-views

Berdasarkan hasil regresi menggunakan Fixed Effect Model (FEM) diatas dapat disimpulkan bahwa nilai konstanta sebesar 7.436300, nilai t-Statistik sebesar 2.761486 dengan probabilitas $0.0093<0.05$.

Koefisien regresi Ukuran Perusahaan sebesar -0.282479 , nilai t-Statistik sebesar -2.930846 dengan probabilitas sebesar $0.0061<0.05$ artinya variabel Ukuran Perusahaan berpengaruh negatif terhadap Kebijakan Hutang dan signifikan pada tingkat $\alpha=5 \%$.

Koefisien regresi Pertumbuhan Perusahaan sebesar 1.018572, nilai t-statistik sebesar 3.234059 dengan probabilitas sebesar $0.0028<0.05$ artinya variabel Pertumbuhan Perusahaan berpengaruh positif terhadap Kebijakan Hutang dan signifikan pada tingkat $\alpha=5 \%$. 
Persamaan regresi yang diestimasi secara simultan dilakukan penguji dengan uji $\mathrm{F}$ diperoleh nila $\mathrm{F}_{\text {hitung }}$ sebesar 406.8447 dengan probabilitas 0.000000 $<0.05$ artinya persamaan ini layak digunakan untuk estimasi. Hasil $\mathrm{R}^{2}$ sebesar 0.994240 merupakan nilai kontribusi variabel independen menerangkan hubungan terhadap variabel dependen yaitu Kebijakan Hutang sebesar $99.4240 \%$ sedangkan sisa sebesar $0.5760 \%$ dijelaskan oleh variabel lain yang tidak digunakan dalam penelitian ini (Santosa, 2016).

\section{Uji Asumsi Klasik}

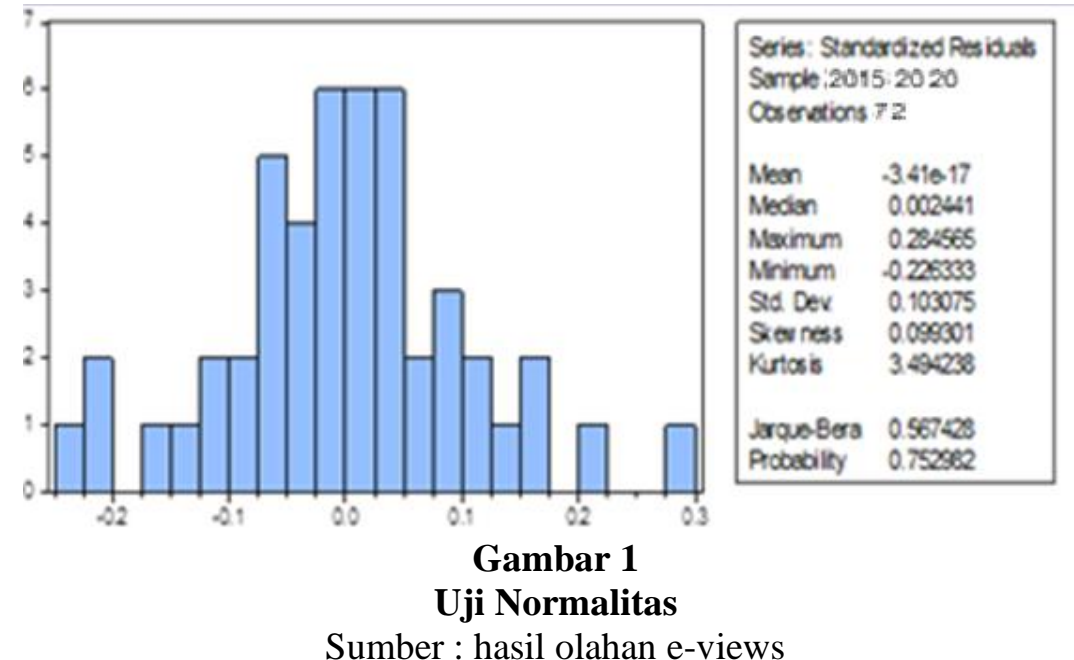

Dapat dilihat histogram uji residual diatas menunjukkan nilai probabilitasnya sebesar $0.752982>0.05$, maka data dapat dikatakan terdistribusi normal.

\section{Uji Multikolinearitas}

Tabel 3.

Hasil Uji Multikolinearitas

\begin{tabular}{ccc}
\hline & Size & Growth \\
\hline Size & 1.000000 & -0.104456 \\
\hline Growth & -0.104456 & 1.000000
\end{tabular}

Sumber : hasil olahan e-views

Berdasarkan tabel diatas dapat diketahui bahwa variabel independent yang terdiri dari Ukuran Perusahaan dan Pertumbuhan Perusahaan bebas dari uji multikoliniearitas karena memiliki nilai dibawah 0.80. Artinya variabel - variabel tersebut layak untuk dipakai dalam penelitian ini. 


\section{Uji Heteroskedastisitas}

Tabel 4

Sample (adjusted) : 20152020

Hasil Uji Heteroskedastisitas

Periods Induded: 6

Cross-sections Induded: 12

Total Panel (balanced) Observations :72

\begin{tabular}{lcccc}
\hline \multicolumn{1}{c}{ Variable } & Coeffcient & Std.Error & t-Statistic & Prob \\
\hline C & 1.745249 & 16.83147 & 0.103690 & 0.9184 \\
Size & -1.365981 & 5.910509 & -0.231111 & 0.8195 \\
Growth & 0.108014 & 0.517620 & 0.208674 & 0.8367 \\
\hline
\end{tabular}

Sumber : hasil olahan e-views

Berdasarkan hasil uji Glejser di atas maka dapat disimpulkan bahwa Ho diterima karena hasil Probabilitas setiap variabel independent $>0,05$. Sehingga dapat disimpulkan bahwa tidak ada masalah heterijedastisitas dalam penelitian ini.

\section{Uji Autokorelasi}

\section{Tabel 5}

Hasil Uji Autokorelasi $D W-$ Test

\begin{tabular}{cccc}
\hline$R$-squared & 0.994240 & Mean Dependent Var & 1.362756 \\
\hline Adjusted $R$-squared & 0.991796 & S.D. Dependent Var & 1.510088 \\
\hline S.E. of regression & 0.123063 & Sum squared resid & 0.499768 \\
\hline F-statistic & 406.8447 & Durbin-Watson Stat & 2.086462 \\
\hline Prob $(F$-statistic $)$ & 0.000000 & & \\
\hline
\end{tabular}

Sumber : hasil olahan e-views

Dari model terbaik dalam regresi yang terbentuk yaitu Fixed Effect Model dapat dilihat bahwa nilai DW dari persamaan regresi yang terbentuk adalah sebesar 2.086462, sedangkan nilai tabel Durbin - Watson dengan $\mathrm{n}=48$ dan $\mathrm{k}=3$, maka diperoleh nilai $\mathrm{dL}=1.4064$ dan $\mathrm{dU}=1.6708$, sehingga nilai 4 -dU $=4-$ $1.6708=2.3292$, yang terletak antara $1.4064<2.086462<2.3292$ maka dengan demikian disimpulkan bahwa autokorelasi yang terbentuk pada penelitian ini yaitu tidak ada autokorelasi (Santosa, 2019).

\section{Uji Hipotesis}

\section{Koefisien Korelasi Berganda}

Dari tabel 5. (FEM) Fixed Effect Model pada tabel diatas didapat koefisien korelasi berganda R2 (Adjusted E-squared) antara Ukuran Perusahaan dan Pertumbuhan Perusahaan adalah $\sqrt{ } 0.991796=0.983659$. Maka angka 0.983659 menunjukan bahwa terjadi hubungan yang sangat kuat antar variabel ukuran perusahaan dan pertumbuhan perusahaan.

\section{Uji Persamaan Regresi Linear Berganda}

Data dari hasil output Eviews di atas didapat persamaan regresi linier berganda sebagai berikut : 


\section{DER $=7.436300-0.282479($ SIZE) $)+1.018572($ (GROWTH $)+\varepsilon$}

Berdasarkan Tabel 4 dan persamaan diatas tersebut dapat dijelaskan pengaruh masing - masing variabel independent terhadap variabel dependen sebagai berikut

1. Konstanta $\propto$ sebesar 7.436300 menyatakan bahwa jika nilai dari Ukuran Perusahaan, dan Pertumbuhan Perusahaan konstan (0) maka besar Kebijakan Hutang adalah sebesar 7.436300.

2. Nilai koefisien regresi Ukuran Perusahaan memiliki hubungan negatif 0.282479 hal ini menunjukan jika setiap Ukuran Perusahaan mengalami peningkatan sebesar 1 maka Kebijakan Hutang akan mengalami peningkatan sebesar -0.282479, sebaliknya jika setiap Ukuran Perusahaan mengalami penurunan sebesar 1 maka Kebijakan Hutang mengalami penurunan sebesar 0.282479 dengan asumsi koefisien regresi variabel lain adalah nol.

3. Nilai koefisien regresi Pertumbuhan Perusahaan memiliki hubungan positif 1.018572 hal ini menunjukan jika setiap Pertumbuhan Perusahaan mengalami peningkatan sebesar 1 maka Kebijakan Hutang akan mengalami peningkatan sebesar 1.018572, sebaliknya jika setiap Pertumbuhan Perusahaan mengalami penurunan sebesar 1 maka Kebijakan Hutang mengalami penurunan sebesar 1.018572 dengan asumsi koefisien regresi variabel lain adalah nol.

\section{Uji Koefisien Regresi Parsial (Uji t)}

Pada tabel 4 yakni tabel $\mathrm{t}$-statistik yang terlampir pada lampiran dengan $\mathrm{df}=$ $(\mathrm{n}-\mathrm{k}-1)=(48-3-1)=44$ dan derajat kebebasan sebesar 0.05 diperoleh tabel sebesar 1.60823 .

1. Uji regresi parsial (Uji t) menunjukan bahwa nilai koefisien regresi Ukuran Perusahaan negatif -0.282479 , nilai $t_{\text {hitung }}-2.930846$ dengan probabilitas sebesar $0.0061<0.05$, maka pengaruh Ukuran Perusahaan terhadap Kebijakan Hutang negatif dan sinifikan.

2. Uji regresi parsial (Uji t) menunjukan bahwa nilai koefisien regresi Pertumbuhan Perusahaan positif 1.018572 , nilai $t_{\text {hitung }} 3.234059$ dengan probabilitas sebesar $0.0028<0.05$, maka pengaruh Ukuran Perusahaan terhadap Kebijakan Hutang positif dan sinifikan.

\section{Uji Koefisien Regresi Bersama - Sama (Uji F)}

Pada tabel 5 yakni tabel $\mathrm{F}$ statistik dan derajat kebebasan 0.05. Berdasarkan tabel di atas, dapat kita bandingkan antara $\mathrm{F}$ hitung sebesar 496.8447 dan $\mathrm{F}$ tabel sebesar 2.09 ( $\left.\mathrm{F}_{\text {hitung }}>\mathrm{F}_{\text {tabel }}\right)$ maka $\mathrm{H}_{\mathrm{a}}$ diterima artinya Ukuran Perusahaan dan Pertumbuhan Perusahaan secara bersama-sama berpengaruh terhadap Kebijakan Hutang.

\section{Uji Koefisien Determinasi}

Pada tabel 5 diatas menunjukan nilai Adjust R-Squared 0.991796 artinya secara bersama-sama variabel Ukuran Perusahaan, dan Pertumbuhan Perusahaan 
berpengaruh terhadap variabel Kebijakan Hutang sebesar $99.1796 \%$ sedangkan sisanya sebesar $0,8204 \%$ dijelaskan oleh variabel lain yang tidak diteliti dalam penelitian ini.

\section{B. Pembahasan}

1. Pengaruh Ukuran Perusahaan Terhadap Kebijakan Hutang Secara Parsial Hasil uji regresi secara parsial menunjukan ada pengaruh Ukuran Perusahaan terhadap Kebijakan Hutang pada tingkat signifikan $\alpha=0.05$, terlihat dari hasil uji $\mathrm{t}$ yang dilakukan diperoleh $\mathrm{t}_{\text {hitung }}$ sebesar -2.930846 dengan probabilitas sebesar $0.0061<0.05$, hasil dari penelitian persamaan regresi di atas terlihat bahwa koefisien regresi bernilai negatif sebesar -0.282479 , artinya variabel Ukuran Perusahaan berpengaruh negatif dan signifikan terhadap Kebijakan Hutang.

Penelitian ini sejalan dengan penelitian (Nazariah, 2014) dan Penelitian (Mentari \& Armia, 2016) yang mengungkapkan bahwa Ukuran Perusahaan berpengaruh terhadap Kebijakan Hutang. Namun, bertentangan dengan hasil dari penelitian (Hatigoran Silitonga, 2014) dan penelitian (Aziz et al., 2019) yang mengungkapkan bahwa Ukuran Perusahaan tidak berpengaruh terhadap Kebijakan Hutang.

2. Pengaruh Pertumbuhan Perusahaan Terhadap Kebijakan Hutang Secara Parsial

Hasil uji resresi secara parsial menunjukan ada pengaruh Pertumbuhan Perusahaan terhadap Kebijakan Hutang pada tingkat signifikan $\alpha=0.05$, terlihat dari hasil uji $\mathrm{t}$ yang dilakukan diperoleh $\mathrm{t}_{\text {hitung }}$ sebesar 3.234059 dengan probabilitas sebesar $0.0028<0.05$, hasil dari penelitian persamaan regresi di atas terlihat bahwa koefisien regresi bernilai negatif sebesar 1.018572, artinya variabel Pertumbuhan Perusahaan berpengaruh positif dan signifikan terhadap Kebijakan Hutang.

Penelitian ini sejalan dengan penelitian Arif Irawan, Rina Arifati, dan Abrar (Irawan et al., 2016). yang mengungkapkan bahwa Pertumbuhan Perusahaan berpengaruh positif dan signifikan terhadap Kebijakan Hutang. Namun, bertentangan dengan hasil dari penelitian (Mentari \& Armia, 2016) dan (Rosdiana, 2014) yang mengungkapkan bahwa Pertumbuhan Perusahaan tidak berpengaruh terhadap Kebijakan Hutang.

3. Pengaruh Ukuran Perusahan dan Pertumbuhan Perusahaan Secara Bersama - Sama Terhadap Kebijakan Hutang

Hasil uji regresi secara bersama-sama menunjukkan pengaruh Ukuran Perusahaan, dan Pertumbuhan Perusahaan dengan melakukan uji F diperoleh $F_{\text {hitung }}$ sebesar 496.8447. Berdasarkan hitung tersebut dapat kita bandingkan antara $\mathrm{F}_{\text {hitung }}$ sebesar 496.8447 dengan $\mathrm{F}_{\text {tabel }}$ sebesar 2.09 ( $\mathrm{F}_{\text {hitung }}>\mathrm{F}_{\text {tabel }}$ ), maka $\mathrm{H}_{\mathrm{a}}$ diterima artinya Ukuran Perusahaan dan Pertumbuhan Perusahaan secara bersama-sama berpengaruh terhadap Kebijakan Hutang. 


\section{Kesimpulan}

Berdasarkan hasil penelitian dan pembahasan dengan hasil regresi menggunakan 3 model pendekatan Common Effect Model (CEM), Fixed Effect Model (FEM) dan Random Effect Model (REM) dapat disimpulkan bahwa Fixed Effect Model (FEM) dianggap sebagai model yang terbaik untuk menganalisis pengaruh Ukuran Perusahaan, dan Pertumbuhan Perusahaan pada perusahaan manufaktur sektor industri barang konsumsi yang terdaftar di Bursa Efek Indonesia periode 2015-2020. Berdasarkan hasil penelitian dan pembahasan, dapat disimpulkan hal sebagai berikut: 1) Hasil uji regresi secara parsial menunjukkan Ukuran Perusahaan berpengaruh negatif dan signifikan terhadap Kebijakan Hutang pada perusahaan manufaktur sektor industri barang konsumsi yang terdaftar di Bursa Efek Indonesia periode 2016-2019. 2) Hasil uji regresi secara parsial menunjukkan Pertumbuhan Perusahaan berpengaruh positif dan signifikan terhadap Kebijakan Hutang pada perusahaan manufaktur sektor industri barang konsumsi yang terdaftar di Bursa Efek Indonesia periode 2016-2019. 3) Hasil uji regresi secara bersama - sama menunjukan Ukuran Perusahaan dan Pertumbuhan Perusahaan memberikan pengaruh terhadap Kebijakan Hutang. 


\section{BIBLIOGRAFI}

Astuti, E. (2015). Pengaruh Kepemilikan Institusional, Profitabilitas, Ukuran Perusahaan Terhadap Kebijakan Hutang Perusahaan Di Indonesia. Jurnal Akuntansi Dan Pajak, 15 (02), 149-158. Google Scholar

Aziz, A. M., Chomsatu, Y., \& Wahyuningsih, E. M. (2019). Pengaruh Kepemilikan Institusional, Profitabilitas Dan Ukuran Perusahaan Terhadap Kebijakan Hutang. Jurnal Ilmiah Edunomika, 3 (02). Google Scholar

Dewi, Gusti Ayu Rencana Sari, D. P. V. (2018). Investasi dan Pasar Modal Indonesia. Rajawali Pers, Cetakan Pertama, 2018. Google Scholar

Gustian, D. (2017). Pengaruh pertumbuhan perusahaan, keputusan investasi, dan keputusan pendanaan terhadap nilai perusahaan (Studi empiris pada perusahaan manufaktur yang terdaftar di Bursa Efek Indonesia 2010-2014). Jurnal Akuntansi, 5 (1). Google Scholar

Hatigoran Silitonga, A. (2014). Pengaruh Kepemilikan Manajerial, Ukuran Perusahaan dan Profitabilitas terhadap Kebijakan Hutang (Studi Empiris Pada Perusahaan Manufaktur Yang Terdaftar Di BEI). Google Scholar

Irawan, A., Arifati, R., \& Oemar, A. (2016). Pengaruh Aset Berwujud, Ukuran Perusahaan, Pertumbuhan Perusahaan, Lama Perusahaan dan Profitabilitas Terhadap Kebijakan Hutang Pada Perusahaan Manufaktur yang Terdaftar di Bursa Efek Indonesia Periode Tahun 2010-2014. Journal Of Accounting, 2 (2). Google Scholar

Mentari, A., \& Armia, S. (2016). Pengaruh faktor demografi terhadap keputusan pembelian mobil di Kota Banda Aceh dengan persepsi merek mewah sebagai variabel mediasi. Jurnal Ilmiah Mahasiswa Ekonomi Manajemen, 1 (1), 23-36. Google Scholar

Mulyanti, D. (2017). Manajemen Keuangan Perusahaan. Akurat| Jurnal Ilmiah Akuntansi FE UNIBBA, 8 (2), 62-71. Google Scholar

Nazariah, N. (2014). Pengaruh Arus Kas Bebas, Kepemilikan Manajerial, Kepemilikan Institusional, Dan Kebijakan Utang Terhadap Kebijakan Dividen Pada Emiten Manufaktur Di Bursa Efek Indonesia. Jurnal Telaah Dan Riset Akuntansi, 7 (1), 58-65. Google Scholar

Riyanto, B. (2001). Dasar dasar pembelanjaan perusahaan. Google Scholar

Rosdiana, E. (2014). Pengaruh Kas Bebas, Kepemilikan Manajerial dan Ukuran Perusahaan Terhadap Kebijakan Hutang pada Perusahaan Manufaktur yang terdaftar di Bursa Efek Indonesia (BEI) Periode 2010-2014. Google Scholar 
Santosa, A. D. (2016). Pengolahan Data E-Views (Cara Operasi dan Proses Analisis), Amara books, Cetakan Pertama. Google Scholar

Santosa, A. D. (2019). Analisis Multivariat, Kepel Press. Google Scholar

Sumarsono, H. (2016). Pengaruh Keputusan Pendanaan, Kebijakan Deviden dan Pertumbuhan Perusahaan Terhadap Nilai Perusahaan. Ekuilibrium: Jurnal Ilmiah Bidang Ilmu Ekonomi, 7 (1), 36-46. Google Scholar

Veronica, A. (2020). Kebijakan Hutang Pada Perusahaan Manufaktur Yang Terdaftar Di Bursa Efek Indonesia. Jurnal Media Wahana Ekonomika, 17 (1), 1-17. Google Scholar

\section{Copyright holder:}

Yusdianto, Achmad Ramadhoni, Sutanto Hardisaputera (2021)

First publication right:

Jurnal Syntax Admiration

This article is licensed under: 